\title{
Evaluation of cytotoxic and antioxidant activity of different fractions of methanolic extract of Baccaurea ramiflora (Lour.) fruits
}

\author{
*Roksana Amin and Md. Nahidun Nabi \\ Department of Pharmacy, Jahangirnagar University, Savar, Dhaka-1342, Bangladesh
}

\begin{abstract}
Chloroform and petroleum ether soluble fractions of the crude methanolic extract of the fruits of Baccaurea ramiflora (Lour.) have been investigated for the evaluation of cytotoxic and antioxidant activity. Brine shrimp lethality bioassay was used to evaluate the cytotoxic activity and free radical scavenging activity method was used to evaluate antioxidant activity. In brine shrimp lethality bioassay, the chloroform soluble fraction showed greater cytotoxic activity $\left(\mathrm{LC}_{50}\right.$ value $\left.74.2 \mu \mathrm{g} / \mathrm{ml}\right)$ than petroleum ether soluble fraction $\left(\mathrm{LC}_{50}\right.$ value $\left.129 \mu \mathrm{g} / \mathrm{ml}\right) \mathrm{compared}$ to the standard drug vincristine sulfate $\left(\mathrm{LC}_{50}\right.$ value $\left.0.54 \mu \mathrm{g} / \mathrm{ml}\right)$. In free radical scavenging activity method (DPPH assay method), the chloroform soluble fraction showed greater antioxidant activity $\left(\mathrm{IC}_{50}\right.$ value $49.78 \mu \mathrm{g} / \mathrm{ml}$ ) than petroleum ether soluble fraction $\left(\mathrm{IC}_{50} \mathrm{value} 75.31 \mu \mathrm{g} / \mathrm{ml}\right) \mathrm{compared} \mathrm{to}$ the standard antioxidant butylated hydroxytoluene ( $\mathrm{IC}_{50}$ value $24.51 \mu \mathrm{g} / \mathrm{ml}$ ). This study reveals that Baccaurea ramiflora fruit possesses cytotoxic and antioxidant activity hence can be a potential source for the isolation of active principle(s) for different therapies.
\end{abstract}

Key Words: Baccaurea ramiflora, cytotoxic activity, brine shrimp lethality bioassay, antioxidant activity, DPPH free radical scavenging assay.

\section{INTRODUCTION}

Plants have been a source of medicinal substances for thousands of years. Plants and phytoproducts continue to play a vital role in the treatment of various diseases including cancer. Drug discovery from plants is a multidisciplinary approach which combines various botanical, ethno-botanicals, phytochemical and biological and chemical separation techniques. However, despite these observations, it is significant that over $60 \%$ of currently used anti-cancer agents are derived from natural sources (Asokan and Thangavel, 2014) and about $80 \%$ of the world's inhabitants' problems are treated by medicinal herbal drug for their primary health care (Ali et al., 2013). Moreover, most of the antioxidant compounds in a typical diet are derived from plant sources and the main characteristic of an antioxidant is its ability to trap free radicals (Sharma et al., 2013) which are constantly formed in the human body by normal metabolic action and exert oxidative damaging effects by reacting with nearly every molecule found in living cells including nucleic acids, proteins, lipids or DNA and may involve in several chronic and degenerative diseases including gastritis, reperfusion injury of many tissues, atherosclerosis, ischemic heart disease, ageing, diabetes mellitus, cancer, immunosuppression, neurodegenerative diseases and others (Lakshmanashetty et al., 2010; Vyas et al., 2010).

Baccaurea ramiflora Lour. syn. B. sapida (Roxb.) Muell.-Arg. (Family: Euphorbiaceae) is native to Southeast Asia region (Goyal et al., 2013) growing wild as well as under cultivation in Nepal, India, Myanmar, Bangladesh, South China, Indo-China, Thailand, , the Andaman island and Peninsular Malaysia (Abdullah et al., 2005) and its fruit is locally known as 'Lotkon'. It is a semi-evergreen tree reaching a height of about $5-10 \mathrm{~m}$. Fruit is yellowish and velvety, 2-3 cm in diameter with leathery pericarp,

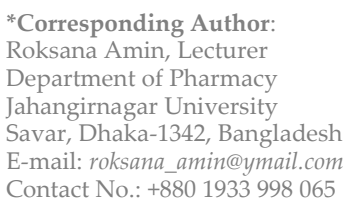

three seeded arillus embedded in pinkish white pulp. $B$. ramiflora fruit finds its importance as a novel food additive because of its high content of vitamin $\mathrm{C}$, protein and iron. The fruit juice is mainly used for the treatment of constipation, whereas different parts of the plant are used to treat arthritis, abscesses and injuries. They are also stewed or made into wine (Goyal et al., 2013).

Fruits are important sources of minerals, fiber and vitamins, which provides essential nutrients for the human health. Increased consumption of fruit and vegetables significantly reduce the incidence of chronic diseases, such as cancer, cardiovascular diseases and offer protection against free radicals that damage lipids, proteins, and nucleic acids (Prakash et al., 2012). So our present study is aimed to investigate cytotoxic and antioxidant potential of chloroform and petroleum ether soluble fractions of methanolic extract of $B$. ramiflora fruits.

\section{MATERIALS AND METHODS}

Plant material and preparation of extracts

The fresh lotkon fruits were collected from Dhaka, Bangladesh in the year 2013 and identified. It was ensured that the fruits were free from contamination, sand and microbial growth.

The fruits of the plant were sun-dried and then, dried in an oven at reduced temperature (not more than $50^{\circ} \mathrm{C}$ ) to make suitable for grinding purpose. Dried powdered fruits $(200 \mathrm{~g})$ were successively extracted using methanol as solvent in a soxhlet apparatus for continuous extraction till exhaustion. The solvent was completely removed and the crude extract thus obtained was used for investigation.

\section{Fractionation}

The concentrated methanolic extract of the plant material was partitioned sequentially by modified Kupchan method (Kupchan and Tsou, 1973; Vanwagenen et al., 1993) and the resultant partitionates i.e., chloroform and petroleum ether soluble fractions were evaporated to dryness. 


\section{Brine shrimp lethality bioassay}

Cytotoxicity of the plant extract was determined by brine shrimp lethality bioassay technique (McLaughlin et al., 1998; Meyer et al., 1982) using brine shrimp eggs i.e., Artemia salina. Vincristine sulfate was used as standard in this bioassay. Shrimp eggs were added to one side of a small tank containing $3.8 \% \mathrm{NaCl}$ and then this side was covered. Two days were allowed to hatch the shrimp and to be matured as nauplii. Constant oxygen supply was carried out through the hatching time. The hatched shrimps were attracted to the lamp through the perforated dam and they were taken for experiment.

Measured amount of each of the samples was dissolved in dimethyl sulfoxide (DMSO) and solutions of varying concentrations such as 500, 200, 100, 50, 20, 10, 5 and $1 \mu \mathrm{g} / \mathrm{ml}$ were obtained by serial dilution technique. Then, the solutions were added to the pre-marked vials containing ten (10) live brine shrimp nauplii in $5 \mathrm{ml}$ simulated sea water. After 24 hours, the vials were inspected using a magnifying glass and the number of survivors were counted. The mortality in percent (\%) was calculated for each dilution by following equation:

$(\%)$ Mortality $=\left[\frac{(\text { Total-Alive })}{\text { Total }}\right] \times 100$

The percentage of mortality was plotted against the logarithm of concentration and the median lethal concentration $\mathrm{LC}_{50}$ of the test sample after 24 hours was calculated and compared with reference standard.

\section{Evaluation of free radical scavenging activity}

The determination of the free radical scavenging activity of the methanolic extract was carried out using the DPPH (1, 1-diphenyl-2 picrylhydrazyl) assay method (Brand Williams et al., 1995). $2.0 \mathrm{ml}$ of a methanol solution of the sample (Control / extractives) at different concentration from 500.0 to $0.977 \mu \mathrm{g} / \mathrm{ml}$ were mixed with $3.0 \mathrm{ml}$ of a DPPH methanol solution $(20 \mu \mathrm{g} / \mathrm{ml})$. After 30 minutes reaction period at room temperature in dark place the absorbance was measured at $517 \mathrm{~nm}$ against methanol as blank by UV spectrophotometer. Inhibition of free radical $\mathrm{DPPH}$ in percent (\%) was calculated as follows-

(\%) inhibition $=\left(\frac{1-A_{\text {sample }}}{A_{\text {blank }}}\right) \times 100$

where Ablank is the absorbance of control reaction (containing all reagents except the test material). Extract concentration providing $50 \%$ inhibition (IC50) was calculated from the graph plotted inhibition percentage against extract concentration.

\section{RESULTS AND DISCUSSION}

\section{Cytotoxic study}

In this study, chloroform and petroleum ether soluble fractions of $B$. ramiflora fruits found to be toxic to brine shrimp nauplii, with LC 50 values of $74.2 \mu \mathrm{g} / \mathrm{ml}$ and 129 $\mu \mathrm{g} / \mathrm{ml}$ respectively (table 1 ) whereas anticancer drug vincristine sulphate showed $\mathrm{LC}_{50}$ value of $0.54 \mu \mathrm{g} / \mathrm{ml}$ (table 2). They might have antitumor activity as the cytotoxicity of plant material is considered to be caused by the presence of antitumor compounds (Rahman and Ahmed, 2013). The brine shrimp lethality bioassay also indicates antifungal effects, pesticidal effects, teratogenic effects, toxicity to environment and many more (Rahman et al., 2014). Chloroform soluble fraction showed higher cytotoxic potential than petroleum ether soluble fraction. The degree of lethality shown by the fractions of methanolic extract was found to be directly proportional to the concentration of the extractives ranging from the lowest concentration $(1 \mu \mathrm{g} / \mathrm{ml})$ to the highest concentration
Table 1: Effect of chloroform soluble fraction (CHF) and petroleum ether soluble fraction (PEF) of the methanolic extract of B. ramiflora fruits on brine shrimp nauplii.

\begin{tabular}{|c|c|c|c|c|c|c|c|c|}
\hline \multirow{2}{*}{$\begin{array}{l}\text { Conc. } \\
(\mu g / m l)\end{array}$} & \multirow{2}{*}{$\begin{array}{l}\text { Log } \\
\text { Conc. }\end{array}$} & \multicolumn{2}{|c|}{ (\%) Mortality } & $\begin{array}{c}\mathrm{LC}_{50} \\
(\mu \mathrm{g} / \mathrm{ml})\end{array}$ & \multicolumn{2}{|c|}{$\begin{array}{c}\text { Regression } \\
\text { equation }\end{array}$} & \multicolumn{2}{|c|}{$\mathbf{R}^{2}$} \\
\hline & & $\mathrm{CHF}$ & PEF & CHF PEF & $\mathrm{CHF}$ & PEF & $\mathrm{CHF}$ & PEF \\
\hline 1 & 0 & 10 & 0 & & & & & \\
\hline 5 & 0.699 & 20 & 10 & & న & $\vec{\nabla}$ & & \\
\hline 10 & 1 & 30 & 20 & & กั & $\stackrel{\infty}{\Lambda}$ & & \\
\hline 20 & 1.301 & 30 & 30 & ฯ & $\dot{x}$ & $\dot{x}$ & $\stackrel{0}{-1}$ & $m$ \\
\hline 50 & 1.699 & 40 & 40 & ম & å & m & హె & ๙ू \\
\hline 100 & 2 & 60 & 40 & & ஜ & ஜ் & & \\
\hline 200 & 2.301 & 80 & 70 & & II & $\|$ & & \\
\hline 500 & 2.699 & 90 & 80 & & $\lambda$ & 7 & & \\
\hline
\end{tabular}

Table 2: Effect of vincristine sulfate on brine shrimp nauplii.

\begin{tabular}{|c|c|c|c|c|c|c|}
\hline $\begin{array}{c}\text { Test } \\
\text { sample }\end{array}$ & $\begin{array}{l}\text { Conc. } \\
(\mu \mathrm{g} / \mathrm{ml})\end{array}$ & $\begin{array}{l}\text { Log } \\
\text { Conc. }\end{array}$ & $\begin{array}{c}(\%) \\
\text { Mortality }\end{array}$ & $\begin{array}{c}\mathrm{LC}_{50} \\
(\mu \mathrm{g} / \mathrm{ml})\end{array}$ & $\begin{array}{c}\text { Regression } \\
\text { equation }\end{array}$ & $\mathbf{R}$ \\
\hline \multirow{8}{*}{ 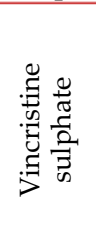 } & 0.06 & -1.2218 & 10 & \multirow{8}{*}{ 華 } & & \multirow{8}{*}{$\begin{array}{l}\infty \\
\stackrel{1}{\sigma} \\
0\end{array}$} \\
\hline & 0.125 & -0.9030 & 20 & & $N$ & \\
\hline & 0.25 & -0.6020 & 30 & & เొ & \\
\hline & 0.5 & -0.3010 & 50 & & $\stackrel{+}{x}$ & \\
\hline & 1 & 0 & 60 & & बे & \\
\hline & 5 & 0.69897 & 90 & & nं & \\
\hline & 12.5 & 1.09691 & 100 & & $\|$ & \\
\hline & 25 & 1.39794 & 100 & & $\lambda$ & \\
\hline
\end{tabular}

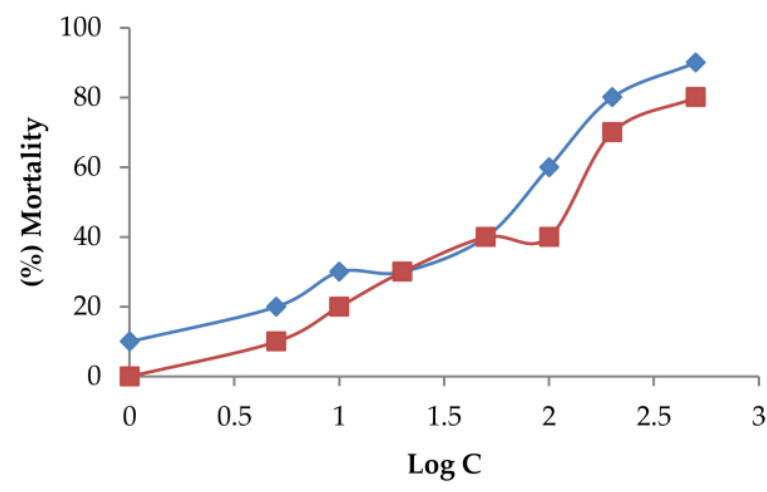

$\longrightarrow$ (\%) Mortality by $\mathrm{CHF} \longrightarrow$ (\%) Mortality by PEF

Figure 1: Effect of chloroform soluble fraction (CHF) and petroleum ether soluble fraction (PEF) of methanolic extract of B. ramiflora fruits on brine shrimp nauplii.

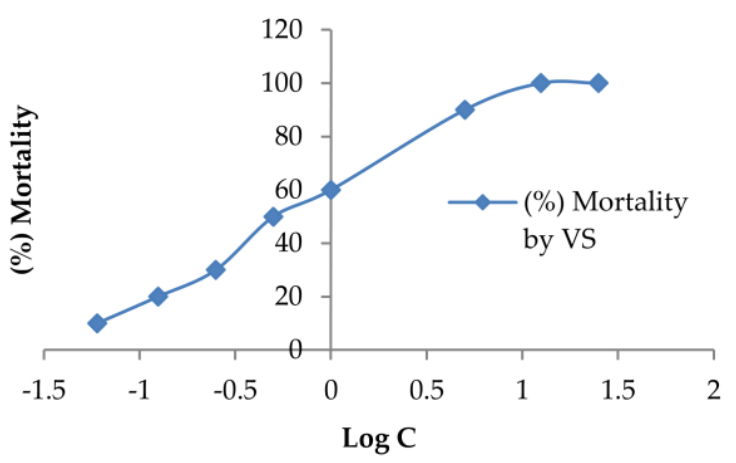

Figure 2: Effect of vincristine sulfate (VS) on brine shrimp nauplii. 
Table 3: Antioxidant activity of chloroform soluble fraction (CHF), petroleum ether soluble fraction (PEF) of methanolic extract of $B$. ramiflora fruits and butylated hydroxytoluene (BHT).

\begin{tabular}{|c|c|c|c|c|c|c|c|}
\hline \multirow{2}{*}{$\begin{array}{c}\text { Absorbance of } \\
\text { blank }\end{array}$} & \multirow{2}{*}{$\begin{array}{l}\text { Conc. } \\
(\mu \mathrm{g} / \mathrm{ml})\end{array}$} & \multicolumn{3}{|c|}{ Absorbance of extract } & \multicolumn{3}{|c|}{ (\%) Inhibition } \\
\hline & & CHF & PEF & BHT & $\mathrm{CHF}$ & PEF & BHT \\
\hline \multirow{10}{*}{0.433} & 500 & 0.049 & 0.072 & 0.042 & 88.7 & 83.4 & 90.3 \\
\hline & 250 & 0.096 & 0.119 & 0.058 & 77.8 & 72.5 & 86.6 \\
\hline & 125 & 0.136 & 0.178 & 0.113 & 68.6 & 58.9 & 73.9 \\
\hline & 62.5 & 0.191 & 0.227 & 0.151 & 55.9 & 47.6 & 65.12 \\
\hline & 31.25 & 0.255 & 0.265 & 0.208 & 41.1 & 38.8 & 51.96 \\
\hline & 15.625 & 0.288 & 0.296 & 0.229 & 33.5 & 31.6 & 47.11 \\
\hline & 7.813 & 0.317 & 0.326 & 0.263 & 26.8 & 24.7 & 39.26 \\
\hline & 3.906 & 0.352 & 0.347 & 0.338 & 18.7 & 19.9 & 21.94 \\
\hline & 1.953 & 0.372 & 0.375 & 0.399 & 14.1 & 13.4 & 7.85 \\
\hline & 0.977 & 0.394 & 0.395 & 0.43 & 9.01 & 8.8 & 0.69 \\
\hline
\end{tabular}

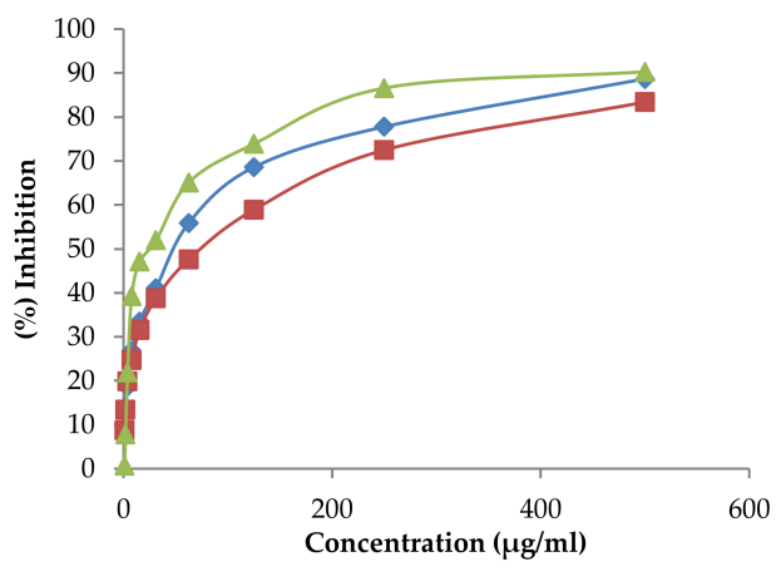

$\longrightarrow$ (\%) Inhibition by $\mathrm{CHF}-(\%)$ Inhibition by PEF - (\%) Inhibition by BHT

Figure 3: Antioxidant activity of chloroform soluble fraction (CHF), petroleum ether soluble fraction (PEF) of methanolic extract of B. ramiflora fruits and butylated hydroxytoluene (BHT).

$(500 \mu \mathrm{g} / \mathrm{ml})$. This concentration dependent increment in percent mortality of brine shrimp nauplii produced by the $B$. ramiflora fruits indicates the presence of cytotoxic principles.

\section{Antioxidant study}

In this study, the chloroform soluble fraction of the methanolic extract of $B$. ramiflora fruits showed strong antioxidant activity with IC 50 value of $49.78 \mu \mathrm{g} / \mathrm{ml}$ and petroleum ether soluble fraction showed good antioxidant activity with $\mathrm{IC}_{50}$ value of $75.31 \mu \mathrm{g} / \mathrm{ml}$ whereas standard antioxidant butylated hydroxytoluene showed $\mathrm{IC}_{50}$ value of $24.51 \mu \mathrm{g} / \mathrm{ml}$ (table 3 and 4 ). As fruits of B. ramiflora produce significant amount of antioxidants to prevent the oxidative stress caused by reactive oxygen species (ROS), it represent a potential source of new compounds with antioxidant activity. Further study will be aimed at isolating and identifying the substances responsible for the antioxidant and cytotoxic activity of extract, which may be further exploited in herbal formulations.

\section{CONCLUSION}

The results from the experiment confirmed that chloroform and petroleum ether soluble fractions of methanolic extract of Baccaurea ramiflora (Lour.) fruit in general,
Table 4: IC 50 values of chloroform soluble fraction (CHF), petroleum ether soluble fraction (PEF) of methanolic extract of B. ramiflora fruits and butylated hydroxytoluene (BHT).

\begin{tabular}{cccc}
\hline Sample & IC $_{50}(\boldsymbol{\mu g} / \mathbf{m l})$ & Regression equation & $\mathbf{R}^{\mathbf{2}}$ \\
\hline CHF & 49.78 & $\mathrm{y}=0.148 \mathrm{x}+28.61$ & 0.727 \\
PEF & 75.31 & $\mathrm{y}=0.138 \mathrm{x}+26.16$ & 0.775 \\
BHT & 24.51 & $\mathrm{y}=0.147 \mathrm{x}+33.73$ & 0.573 \\
\hline
\end{tabular}

possess cytotoxic and antioxidant activity. Therefore consumption of the fruit could offer health benefits in terms of prevention of diseases caused by oxidative stress and cancer. However, further studies are suggested to be undertaken to understand the underlying mechanism of the observed activities and to isolate, identify and purify the cytotoxic and antioxidant components present in it.

\section{ACKNOWLEDGEMENT}

The authors are very thankful to Mrs. Anjuman Ara Begum, Lecturer, Department of Pharmacy, Jahangirnagar University, Savar, for this expert planning, sincere direction, supervision, invaluable advices and continuous follow up from the very beginning of this work.

\section{REFERENCES}

Abdullah, A. T. M., Hossain, M. A. and Bhuiyan, M. K. (2005). Propagation of latka (Baccaurea sapida Muell.Arg.) by mature stem cutting. Research Journal of Agricultural and Biological Sciences, 1(2): 129-134.

Ali, M. R., Hossain, M., Runa, J. F. and Hasanuzzaman, M. (2013). Preliminary cytotoxic activity of different extracts of Averrhoa bilimbi (fruits). International Current Pharmaceutical Journal, 2(3): 83-84. [DOI]

Asokan, A. and Thangavel, M. (2014). In-vitro cytotoxic studies of crude methanolic extract of Saraca indica bark extract. IOSR Journal of Pharmacy and Biological Sciences (IOSR-JPBS), 9(4): 26-30. [DOI]

Brand-Williams, W., Cuvelier, M. E. and Berset, C. (1995). Use of a free radical method to evaluate antioxidant activity. LWT-Food Science and Technology, 28: 25-30. [DOI]

Goyal, A. K., Mishra, T. and Sen, A. (2013). Antioxidant profiling of Latkan (Baccaurea ramiflora Lour.) wine. Indian Journal of Biotechnology, 12: 137-139.

Kupchan, S. M. and Tsou, G. (1973). Tumor inhibitors, a new antileukemic simaroubolide from Brucea antidysenterica. The Journal of Organic Chemistry, 38: 178-179. [DOI]

Lakshmanashetty, R. H., Nagaraj, V. B., Hiremath, M. G. and kumar, V (2010). In vitro antioxidant activity of Vitex negundo L. leaf extracts. Chiang Mai Journal of Science, 37(3): 489-497.

McLaughlin, J. L., Anderson, J. E., Rogers and Lingling, L. (1998). The use of biological assays to evaluate botanicals. Drug Information Journal, 32: 513-524.

Meyer, B. N., Ferringni, N. R., Puam, J. E., Lacobsen, L. B., Nichols, D. E and McLaughlin, J. L. (1982). Brine shrimp: a convenient general bioassay for active constituents. Planta Medica, 45: 31-32. [DOI] 
Prakash, D., Upadhyay, G., Gupta, C., Pushpangadan, P. and Singh, K. K. (2012). Antioxidant and free radical scavenging activities of some promising wild edible fruits. International Food Research Journal, 19(3): 1109-1116.

Rahman, M. A. and Ahmed, N. U. (2013). Phytochemical and biological activities of ethanolic extract of C. hirsute leaves. Bangladesh Journal of Scientific and Industrial Research, 48(1): 43-50. [DOI]

Rahman, M. M., Ahmed, A., Sunny, S. S., Atanu, M. S. H., Faruque, A. and Rana, M. S. (2014). In-vitro evaluation of cytotoxic and anthelmintic activity of Luffa acutangula, Luffa aegyptiaca and Momordica cochinchinensis. British Journal of Pharmaceutical Research, 4(2): 267-277. [DOI]
Sharma, R. A., Yadav, A and Bhardwaj, R. (2013). DPPH free radical scavenging activity of phenolic compounds in Argemone mexicana Linn. International Journal of Pharmacy and Pharmaceutical Sciences, 5(3).

Vanwagenen, B. C., Larsen, R., Cardellina, J. H., Randazzo, D., Lidert, J. C. and Swithenbank, C. (1993). Ulosantoin, a potent insecticide from the sponge Ulosa ruetzleri. The Journal of Organic Chemistry, 58: 335-337. [DOI]

Vyas, N., Tailang, M. and Gavatia, N. P. (2010). Antioxidant potential of Psidium guajava Linn. International Journal of Pharmtech Research, 2: 417-419. 